\title{
A case of Japanese encephalitis in a 20 year-old Spanish sportsman, February 2013
}

P Doti $^{1}$, P Castro 1 , M J Martínez ${ }^{2,3}$, Y Zboromyrska ${ }^{2}$, E Aldasoro ${ }^{3}$, A Inciarte ${ }^{1}$, A Requena $^{3}$, J Milisenda ${ }^{1}$, S Fernández $^{1}$, J M Nicolás $^{1}$, J Muñoz (jose.munoz@cresib.cat) ${ }^{3}$

1. Medical Intensive Care Unit, Hospital Clínic, Barcelona, Spain

2. Department of Clinical Microbiology, Hospital Clínic, Barcelona, Spain

3. Barcelona Centre for International Health Research (CRESIB, Hospital Clínic-Universitat de Barcelona), Barcelona, Spain

Doti P, Castro P, Martínez MJ, Zboromyrska Y, Aldasoro E, Inciarte A, Requena A, Milisenda J, Fernández S, Nicolás JM, Muñoz J. A case of Japanese encephalitis in a 20 year-old Spanish sportsman, February 2013. Euro Surveill. 2013;18(35):pii=20573. Available online: http://www.eurosurveillance.org/ViewArticle. aspx?Articleld $=20573$

Article submitted on 22 August 2013 / published on 29 August 2013

We report a severe case of imported Japanese encephalitis (JE) in a healthy young Spanish traveller who developed symptoms after spending three weeks in a touristic area of Thailand. The patient was diagnosed in Thailand and subsequently transferred to Barcelona, Spain, where the Thai laboratory results were confirmed based on IgM serology. Although JE is a rare disease in travellers, this case illustrates the need for seeking travel medical advice before visiting tropical countries.

\section{Case description}

A 20 year-old Spanish man, without relevant past medical history, travelled to Thailand on 25 January 2013 to participate in a martial art competition. The expected duration of the trip was a month and a half. He had not attended a travel clinic before departure and was not prescribed or did not take malaria chemoprophylaxis. Upon arriving in Thailand, he visited Bangkok during two days where he stayed in a hotel. On 28 January he travelled by bus to Surat Thani, and on the same day he took the ferry to Koh Samui island. He stayed at bungalows in the beach (Chaweng and Lamai beaches) during all the stay. In Koh Samui, he trained every day but he also visited rural areas, went in the forest and visited waterfalls where was bitten by mosquitoes.

\section{Clinical picture and laboratory results}

during hospital stay in Thailand

On 21 February, he was admitted to a local hospital in Koh Samui with a 48 hours history of fever $\left(\geq 38^{\circ} \mathrm{C}\right)$, myalgia, malaise and headache. Twenty-four hours after admittance, his condition worsened and photophobia, vomiting and decreased level of consciousness occurred. Physical examination revealed neck stiffness and Glasgow coma score (GCS) 11. Fortyeight hours later the patient presented seizures, $V$ and VII left peripheral nerves palsy with right hemiparesis, and GCS decreased to nine. Intubation and invasive mechanical ventilation were required. Empiric treatment was initiated with ceftriaxone, doxycycline, aciclovir, dexamethasone and phenytoin. After five days the patient was tetraparetic and did not respond to simple commands. A tracheotomy was made and weaning from mechanical ventilation was started.

Initial full blood count, urine test and chest X-ray were normal. A cerebral computed tomography (CT) showed meningeal enhancement.

Cerebrospinal fluid (CSF) analyses revealed a clear fluid with 960 leucocytes $/ \mathrm{mm}^{3}$ (norm: 4,000-10,000/ $\mathrm{mm}^{3}$ ) with $86 \%$ of mononuclear cells, and normal glucose and proteins. Multiple bacterial cultures including mycobacteria, polymerase chain reaction (PCR) for herpes virus, varicella-zoster virus, enterovirus, and rabies virus, blood and CSF Cryptococcus antigen, malaria blood smear and serological tests for human immunodeficiency virus (HIV), dengue virus, Leptospira species, Rickettsia species and Burkholderia pseudomallei were negative.

Real time-polymerase chain reaction (RT-PCR) for Japanese encephalitis virus (JEV) in CSF was negative. The result of IgM against JEV in serum was positive using an IgM capture enzyme-linked immunosorbent assay (ELISA) (IgM in CSF was not performed).

\section{Clinical and laboratory results}

after return to Spain

On 23 March, after being diagnosed in Thailand as a probable case of Japanese encephalitis (JE), he was transferred to our hospital in Barcelona, Spain. A cerebral magnetic resonance image (MRI) showed extensive patchy lesions in left basal nuclei, midbrain, both hippocampi, left caudate nucleus, both internal capsule and left thalamus (Figure).

A serum sample was obtained and an immunofluorescence assay against four flaviviruses was performed (Euroimmun). This test detects antibodies against JEV, 


\section{FIGURE}

Brain magnetic resonance images of a Spanish traveller returning from Thailand with Japanese encephalitis 35 days post-onset of symptoms, Spain, 26 March 2013
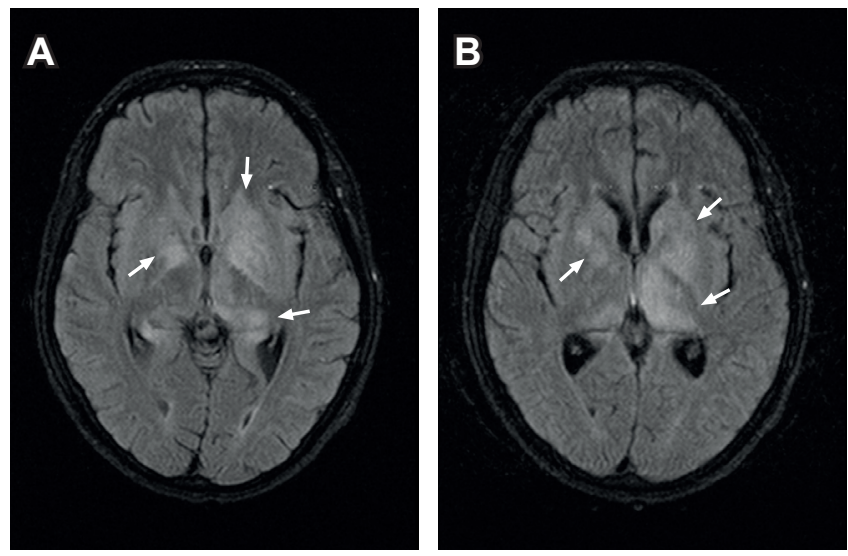

Images in fluid attenuated inversion revovery (FLAIR) sequence. Extensive patchy lesions in left basal nuclei and both hippocampi are visible (white arrows).

West Nile virus (WNV), tick-borne encephalitis and yellow fever viruses. The IgM and IgG antibody titres against JEV were positive (titre: 1:100), while antibodies against the other flaviviruses included in the assay showed lower reactivity. Antibodies against dengue virus measured by ELISA (PanBio) showed borderline values for both IgM and IgG.

No CSF sample for antibody testing was obtained at our hospital since the patient's condition was stable and therefore lumbar puncture was not indicated for medical reasons. A second serum sample obtained two months after the transfer to our hospital showed an IgG titre against JEV of 1:1,280 and an IgM titre of 1:4. The serological reactivity to WNV was limited to a titre of $1: 80$.

In the absence of CSF samples tested for antibodies and seroneutralisation tests, the laboratory results would not fulfil all the requirements for a JE confirmed case, taking the European Union case definition for WNV as a model [1]. However, the diagnosis of JEV infection is strongly supported by (i) a positive IgM using capture ELISA, (ii) both positive IgM and IgG by immunofluorescence, (iii) a rise in IgG titres in paired samples and (iv) lower serological reactivity to other closely related flaviviruses.

Our patient did not present further medical complications. He was able to breathe spontaneously without support and gradually presented clinical improvement, and he was moved to a recovery centre on 15 April, 55 days after onset of symptoms. At the end of June, the patient is able to walk but with an ataxic gait and he presents slight or minor memory impairment and emotional lability without any language disorders.

\section{Conclusion}

JE is a mosquito-borne viral infection, and an important cause of encephalitis in rural and semi-rural areas in Asia [2]. Although 35,000 to 50,000 cases are estimated to occur annually throughout Asia and parts of the western Pacific, it is estimated that the risk for travellers to these areas remains very low. So far only 62 cases have been published in patients not living in endemic areas from 1973 to 2013, and Thailand was the place of exposure for more than one third of the cases reported in non-endemic countries [3-8]. There is an effective vaccine against the disease, recommended for travellers depending on the destination, season, activities and duration of the trip [9-10].

Even though there are few symptomatic cases diagnosed, more than 30 imported cases have been described in Europe since 1973 [3], and we present the first case of JE described in Spain. The diagnosis of JE infection requires high quality reference laboratories, with appropriate tools to perform the diagnosis and expertise for interpretation of results. This case came from a touristic area of Thailand, visited by thousands of tourists from all over the world every year. Despite the availability of a safe vaccine against JE, many people travel unvaccinated either because they do not receive pre-travel advice before departure or because the vaccine is not indicated. This case illustrates the need for seeking travel medical advice before visiting tropical countries. At such consultations, the risk for travellers should be assessed individually on the basis of their planned itinerary and activities, and it is important to inform travellers about personal protection measures against vector-borne disease (using mosquito repellent, wearing protective clothing).

\section{Acknowledgements}

We would like to thank Dr. C. Suchato, Dr. U. Nuch-intra, Dr. P. Narkwiboonwong from the Bangkok Hospital Samui, and Dr. S. Choochumporn, Dr. K. Singh and Dr. P. Chittamnarn from the Bangkok Hospital Medical Centre for the excellent management of the case in their hospitals.

This material is based upon work supported by grant 2009SGR385 from the Department d'Universitats, Recerca I Societat de la Informació de la Generalitat de Catalunya, Spain.

Conflict of interest

None declared.

Authors' contributions

Pamela Doti had full access to all the clinical records and elaborated all the drafts of the manuscript; Pedro Castro and José Muñoz had full access to all the clinical records, revised all the drafts of the manuscript, and had substantial contribution to conception of the manuscript; Mikel J. Martínez reviewed all microbiological data and revised microbiological 
issues of the manuscript; Yuliya Zboromyrska drafted the microbiological part of the manuscript and made critical revision of the latter drafts of the manuscript; Edelweiss Aldasoro, Alexy Inciarte, Ana Requena, José Milisenda, Sara Fernández and José María Nicolás had full access to all the clinical records and made critical revision of the latter drafts of the manuscript.

\section{References}

1. Commission decision of 28 April 2008 amending Decision $2002 / 253 /$ EC laying down case definitions for reporting communicable diseases to the Community network under Decision No 2119/98/EC of the European Parliament and of the Council. Official Journal of the European Union. Luxembourg: Publications Office of the European Union. 18.6.2008. L 159/46. Available from: http://eur-lex.europa.eu/LexUriServ/ LexUriServ.do?uri=0J:L:2008:159:0046:0090:EN:PDF

2. Halstead SB, Thomas SJ. Japanese Encephalitis: New Options for Active Immunization. Clin Infect Dis. 2010;50(8):1155-64. http://dx.doi.org/10.1086/651271 PMid:20218889

3. Hills SL, Griggs AC, Fischer M. Japanese Encephalitis in Travelers from Non-Endemic Countries, 1973-2008. Am J Trop Med Hyg. 2010;82(5):930-6. http://dx.doi.org/10.4269/ ajtmh.2010.09-0676 PMid:20439978 PMCid:PMC2861377

4. Centers for Disease Control and Prevention (CDC). Japanese Encephalitis in a U.S. Traveler Returning from Thailand, 2004. MMWR Morb Mortal Wkly Rep. 2005;54(5):123-5.

5. Centers for Disease Control and Prevention (CDC). Japanese encephalitis in two children--United States, 2010. MMWR Morb Mortal Wkly Rep. 2011;60(9):276-8. PMid:21389931

6. Werlinrud AM, Christiansen CB, Koch A. Japanese encephalitis in a Danish short-term traveler to Cambodia. J Travel Med. 2011;18(6):411-3. http://dx.doi.org/10.1111/j.17088305.2011.00565.x PMid:22017718

7. Langevin $S$, Libman $M$, Drebot $M A$, Laverdière $M$. A case of Japanese encephalitis virus infection acquired during a trip in Thailand. J Travel Med. 2012;19(2):127-9. http://dx.doi. org/10.1111/j.1708-8305.2011.00582.x PMid:22414040

8. Tappe D, Nemecek A, Zipp F, Emmerich P, Gabriel M, Güther S, et al. Two laboratory-confirmed cases of Japanese encephalitis imported to Germany by travelers returning from Southeast Asia. J Clin Virol. 2012;54(3):282-5. http://dx.doi.org/10.1016/j. jcv.2012.03.004 PMid:22465340

9. Fischer M, Lindsey N, Staples JE, Hills S; Centers for Disease Control and Prevention (CDC). Japanese encephalitis vaccines: recommendations of the Advisory Committee on Immunization Practices (ACIP). MMWR Recomm Rep. 2010;59(RR-1):1-27.

10. Trent DW, Minor P, Jivapaisarnpongc T, Shind J, WHO Working Group on the Quality, Safety and Efficacy of Japanese Encephalitis Vaccines (Live Attenuated) for Human Use. WHO working group on the quality, safety and efficacy of Japanese encephalitis vaccines (live attenuated) for human use. WHO working group on the quality, safety and efficacy of Japanese encephalitis vaccines (live attenuated) for human use, Bangkok, Thailand, 21-23 February 2012. Biologicals. 2013 Jul 24. pii: S1045-1056(13)00059-6. 